Özgehan Özkan

Karadeniz Technical University, ozgehan8@yahoo.com.tr, Trabzon-Turkey

DOI $\quad$ http://dx.doi.org/10.12739/NWSA.2018.13.1.4C0221

ORCID ID $0000-0002-2556-0237$

CORRESPONDING AUTHOR Özgehan Özkan

\title{
PRESENTATION OF SCI-TECH NEWS IN THE INTERNET MEDIA
}

\begin{abstract}
Science news which also includes health news, it should be shown awareness in regard to compliance with ethical principles. Besides that, it can be seen especially in parallel with "Click"-"Advertising" equation in the internet media that an attitude of negligence towards the reality and the discourse of scientific source arises. The objective of this study is to determine in what way science news is presented in the internet media. It is also aimed at revealing to what extent national media institutions digress-in particular through headlines, photographs and spots-from the scientific context of the subject in science news added on their websites, in order to be able to increase "the potential of clicking". The sampling in this study has been chosen from science news shown on websites of national media institutions. When taking into consideration analyses regarding news seen in the internet media, it has been found out that headlines, spots and photographs do not truly reflect the real situation and some information in the news is added, modified or removed, briefly the news becomes deceptive in order to get more clicks and increase advertising revenues. According to the occupational principles of the press, it is required that all media institutions make news completely, truly, correctly, multifacetedly and by adhering to discourse of news source. It is seen that the internet media neglects these principles in some news and deceives their readers.
\end{abstract}

Keywords: Internet, Media, Science, News,

\section{INTRODUCTION}

The earth forming 4.5 billion years ago and the life starting 3.5 billion years ago will inevitably come to an end following the sun completely depleting its energy. This is a natural process of depletion. On the other hand, the human who is both the most intelligent and the most "destructive" species accelerates this natural depletion process. He causes life to come to an end by quickly consuming fossil energy sources, polluting air, water and soil, and destructing food and drinking water sources immoderately and uncontrolledly. However, some scientific studies are carried out in order to reduce this destruction, take precautions and make positive improvements. These studies include a broad range from macro to micro level, e.g. from the possibility of producing energy from grass to establishing a new life on another planet. All these developments are among the most important news subjects relating the whole mankind. That's why it is necessary that science news is written in compliance with the nature of science, free from any exaggerations, speculations and lies, as well as conveyed to readers by being compiled by beat reporters. Knowledge always means "power" not only in today's hi-tech world, but also from prehistoric ages to historical ages, which start 
Özkan, Ö.

Humanities Sciences (NWSAHS), 4C0221, 2018; 13(1): 1-16.

with the invention of writing. The element that keeps the human alive in the prehistoric ages, despite of all his physical incapabilities compared with all other creatures and, what is more, makes him the dominant creature of the planet is the knowledge that allows him to benefit from the nature and achieve superiority over it. It is also because of the knowledge that the global balance of power in the First Ageis in favor of the East, not the West like today.Besides the writing, Sumerians who broke new grounds in many fields such as astronomy, education, agriculture, art etc. and the knowledge spreading and progressing through the Sumerians turned the balance of power for the East.However, from the 18th century on, the West takes possession of the "knowledge", namely the power, as a result of the Industrial Revolution, which started and developed in Europe.

The primary way to penetrate into the knowledge and put it into at the human's disposal is to have in-depth knowledge in narrowed fields rather than the superficial and speculative knowledge in many fields.This is not only for those who produce the knowledge, but also relay and learn it. The development of a society depends not only on scientists' studies, but also a comprehensive process containing the whole of the social structure. It is less likely that knowledge not adopted by the base of societycontributesto the development of societies. In a very short period of time after the printing press was invented in the 1st century, almost every house had a chance to access to printed texts and knowledge was adopted and indigenized by the whole of the society. However, the printing press which came out in the Turkish society with a delay of 3 centuries could not receive the same social acceptance. This is just an example from recent history that points out the importance of appropriating the knowledge for the whole of the society. The media reports on developments conducted by scientiests and readers have knowledge about it through the content of the relevant news item. In this regard, this points out the importance of the specialisation in the media serving as a primary news source that allows the society to be informed of and have knowledge about emerging developments both in its own country and in the rest of the world. In order to relay correct, reliable, and speculation-free knowledge to readers, it is required that the journalist who writes a news article should be a beat reporter who has a good command of the literature in its own field and have already performed preliminary readingson the relevant topic.

\section{RESEARCH SIGNIFICANCE}

Knowledge is power. This truth has reached up to the present as a constant rule since the beginning of human existence. Those who have knowledge and scientific knowledge will retain the strongest position. Only with scientific knowledge it is possible to contribute positively to the mankind and ensure its development. Following the process driven by the Industrial Revolution, today's developed societies have been shaped. Researches in the fields such as astronomy, health, archaeology, geology still continue and new findings emerge. These findings, on the one hand, have a potential to make an impact on the life of the whole mankind in the long term, on the other hand, make some small contributions to the daily life. The societies' competence in all these developments is both an indispensable condition for being a "Knowledge Society" and a necessity for making children and the youth feelmotivated and enthusiastic about research. The primary way of competence in these developments is the press, especially the news media of the Internet as a branch of the press. The fact that the Internet has come into use within decades at a global scale and people 
Özkan, Ö.

Humanities Sciences (NWSAHS), 4C0221, 2018; 13(1): 1-16.

access the knowledge as easily as they can carry it "in their pockets" has directed people to question the future of the printed press and the habit of reading newspapers has changed to the digital environment. In this case, the question of how scientific developments are conveyed to readers in the Internet news media has emerged as an issue worth researching. The importance of this research is to address the issue, and to question how to correctly and fully inform the digital society that wants to access the information in the shortest and easiest way.Shouldscientific developments be conveyed specifying the source of the news, explaining in detailwhat resource the development subject of the news is based on? Or has it been taken out of context? Should it be written in speculative language? Are the images used in the news actually related to the topic? Asking this and similar questions, should the news media include correct and full "'must-be-there'" information in line with professional ethics, or provide a service to the 'post truth'' society via magazine-style, enjoyable, far-fetched content? The answer given to these questions within the research constitutes the importance of the research.

\section{BEAT REPORTING IN THE TURKISH MEDIA}

The specialisation in the Turkish press is not at desired level of quality, especially because of problems arising from proprietary structure of media institutions and economic infrastructure. Press institutions do not have features of being a public utilityany more which is treated as a4th power alongside the legislature, the executive and the judiciary and gives accurate information to its readers and protect them against the manipulative effects of economic and political centers of power. On the contrary, media institutions have become, in the econonicsense, a power elite which gives priority to variables in commericalprofit-loss formulas. "The ethical distances" with the economic power elite as a result of advertising revenuesandwith political powers as a result of business activities carried out separately from the mediahave disappeared. "In paralel with becoming the mass media more and more common around the world and their increasing influence over the society, media institutions whose primary duty is originally to gather information about news, relay the news as it happens, provide a flow of information, have obtained a rather political and commercial status, especially as a result of changes caused by economic conditions" [1].

This has caused news to become a "product" that is entertaining, attention-grabbing, unsophisticatedand detached from its real context; instead of real "knowledge", which is read, understood and thought about. In these circumstances, the necessity for beat reporters also disappears automatically. As a matter of fact, beat reportersrelaytheaccurate information to their readers, with knowledge and consciousnessthat are acquired by researches on their own specialized field, so that this causesreaders/advertisers who are "willing to have fun" to escape from it, in other respects, reporters who can be employed with a much lower cost compared to beat reportersare not expected to have graduated from the faculty of communication as well as are not even required to have a college degree compile the news content. This also provides a cost advantage desired by media institutions acting as a commercial enterprise.

Media is no longer a medium from which audience can get the most accurate and reliable information. According to the Şahin'sexpressions [2], traditional media owners whose primary activity is journalism and who carry out this activity by passing down from father to son, have been excluded from the sector in the context of newly emerging 
Özkan, Ö.

Humanities Sciences (NWSAHS), 4C0221, 2018; 13(1): 1-16.

economic dynamics and, instead of them, businessmen who have acquired capital assets in very different sectors and whose primary activity is in no case associated with the journalism have dominated the sector. The new appearance of the global economic structure reflecting to national economies, proprietary structure of the media arising as a result of the new appearance of the national economy and professional structure of staff employed by media institutions have -as a process in which they successively affect each other- brought along an understanding of speculative and of-poor-quality journalism. "In order to be able to bring down the reporting costs, media companies prefer to employ persons who are inexperienced, newbie, or work as an intern, either for a very low salary or without paying anything; instead of journalists who are well-trained with high educationalfees, specialized, experienced" [3].

Educating beat reporters is a process associated with high costs for media companies. Concerning this matter, Gün [4] states that today most of channels and newspapers employ 9-10 reporters, they are requested to instantly present/publish news articles regarding the relevant topic, and, therefore, it is very hard for a reporter to become educated and specialized on a specific field. In other words, media institutions see no harm in compromising on quality, giving priority to the motivation of instantly arousing intense interest of readers. This can be seen more obviously when a local press is reviewed. It is also clearly seen that number of beat reporters employed in specific fields such as sport, magazine and politics is proportionately much more than those whoare specialized on science news, and, consequently, the science reporting is not considered as important by media institutions and attaching importance to it is also not preferable. It is beyond doubt that health reporting is an area that the general public is mostly interested in among science news and hasdirect impacts on people's lives. Based on a news article appearing on the media, readers can get involved in anapplication that may affect their health. However, "there is, in the context of health reporting, no sufficient institutionalisation and specialisation in the national press" [5].

Just like in any product and service industry, it is also essential for media institutions to offer a "product" with a charming and attractive "package" and increasingly maintain tangible recycling process. The way to do this is not to relay scientific and real information to readers by employing beat reporters in each specific news category such as science, education, culture, art, economy etc., but to present news in a speculative manner and maximise the profit considering factors such as rating, click rate or circulation. The same also applies for audiences, i.e. recipients of the news content. Today, news is not considered as information by audiences, but asanentertaining and consumable product. Readers have no time enough to read an informative, "serious" news article, which has been reviewed in-depth and written by a specialized reporter. Contrarily, superficial and speculative news articles whose content consists of headline, spot and visuals is regarded as more desirable and preferableby audiences.

In other words, there exists a perfect harmony between media institutions and readers. The determinant factor for the relation between the media and the public is not the information, but a batch of images and visuals, which are speculated and detached from its context. News is no longer regarded as information, but as an entertaining material.Tabloidismis not regarded as an area of specialisation in the journalism any more, instead of this, all areas 
Özkan, $\ddot{0}$.

Humanities Sciences (NWSAHS), 4C0221, 2018; 13(1): 1-16.

of specialisation in the journalism is tabloidized. This is also applicable for science news. According to the Uzunoğlu's expressions [6], what lies behind the problem why science news is not made is that big capital owners do not make investments for the development of science, but for their products. The Uzunoğlu's conclusion is obviously justifiable when health news existed as part of science news is reviewed. The motivation of selling products, instead of giving information, leads to a divergence from the scientific foundation.

\section{EDUCATION ON BEAT REPORTING IN FACULTIES OF COMMUNICATION IN TURKEY}

Apart from the universities in the Turkish Republic of Northern Cyprus, there are 67 faculties of communication in Turkey. The lectures given in regard to beat reporting in these faculties of communication are as follows:

Lecture on "Beat Reporting/Specialized Reporting":4 faculties

Lecture on "Science and Technology Reporting":2 faculties

Lecture on "Health Communication and Reporting":4 faculties

Lecture on "Tabloid Reporting": 6 faculties

Lecture on "Court Reporting":5 faculties

Lecture on "Economic Reporting": 4 faculties

Lecture on "Sport Reporting":6 faculties

Lecture on "Political Reporting":2 faculties

Lecture on "Travel Reporting":2 faculties

Lecture on "Culture and Arts Reporting":2 faculties

Lecture on "Environmental Reporting":2 faculties

Lecture on "Educational Reporting":1 faculty

Lecture on "War Reporting":2 faculties

As incidated above by the figures, the faculties of communication are also not sufficient to educate beat reporters. What is more, today, even the areas of specialisation mentioned above are divided into sub-areas of specialisation in themselves. Doğan [7] states that educational institutions remain incapable of satisfying the demand for qualified, well-trained and specialised employees required by the today's media and, now, it is compulsorily required forevery area of specialisationto become specialised in it, as the dimensions of the reporting have enlarged. Giving an example from his own area of specialisation, economic reporting, Doğanexpresses that the accumulation of knowledge in the fields such as macroeconomics, money markets, real estate markets, securities markets, agricultural product markets, logistics etc. is respectively required.

\section{ANALYSIS: SCIENCE NEWS IN THE INTERNET MEDIA}

In this survey, the presentation of science news published on the websites of the national mass-circulation newspapers like Hürriyet, Milliyet and Habertürk will be analysed. By taking into the consideration the limitations of the survey, not thewhole content of news, only its headlines and visuals functioning as main factor in the Internet media which stimulates readers "to click" and directs them to read the whole news contentwill be analysed. The news items have been chosen by the random sampling method. The topics of the news items have been limited to 4 groups:

- Health News

- Archeology News

- GeologyNews

- Astronomy News 


\subsection{Health News}

5.1.1. The Newspaper "Hürriyet" (04.08.2017)

Headline: 5 Herbs that protect from anxiety

Analysis: In the headline of the news item, a highly assertive and certain expression like "that protect from anxiety" has been used.In the news content, it is also not spoken of a psychiatrist's name as a reference. It is a misleading news item that can cause readers to move away from getting medical support, diagnose and treat themselves.

\subsubsection{The Newspaper "Milliyet" (18.08.2017)}

Headline: Interesting Method to Pass a Kidney Stone (Gallery News of 5 Pages).

Figure 1. According to newspaper's claim kidneystone which passed by some vegetables

Analysis: The news item is in the shape of a multi-page gallery that proceeds by clicking.In the headline, there is an assertive expression that points to a certain conclusion, and when the content of the news item is reviewed, it is seen as the information source that "people have tried it and obtained satisfying results". There is no mention of a scientific expressionspecified by any nephrologist or anybody else.

\subsubsection{The Newspaper "Habertürk" (30.08.2017)}

Headline: Benefit of Biting Nails.

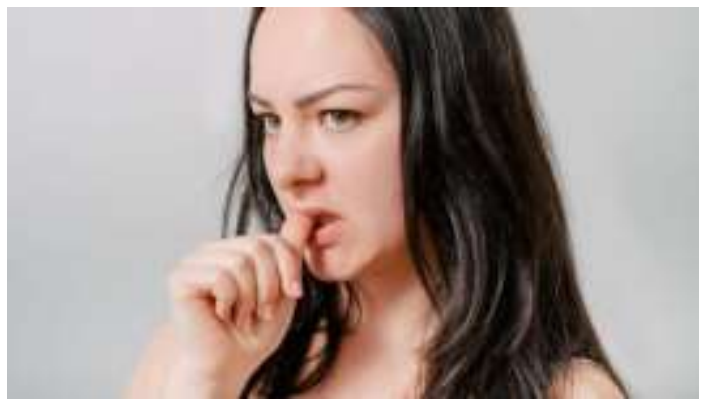

Figure 2. According to the newspaper's claim, biting nails is useful for health

Analysis: "Biting nails" is a multifaceted medical issue that may also be related both to psychiatric problems and microbe-derived physical illnesses. It is mentioned in the headline of the news item that this behaviour has "benefits", with a contradictory and "misleading" expression for readers. When the content of the news item is reviewed, it is seen that the statement "a study published in the 
Pediatrics" is shown as the informationsource.Assuming that the publication in question is known by readers, no explanatory statement has been mentioned in the content of the news item about whether it is an academic journal or a popular publication that only contains pediatric news and in which country, at which university and to what extent the study has been carried out. The argument which is put forward is only the statement "biting nails may be beneficial". However, there is no information about reasons and damages of this behaviour.

\subsection{Archeology News}

5.2.1. The Newspaper "Hürriyet" (06.05.2017)

Headline: Mysterious Events in the Neighborhood Where Russian General was Found.

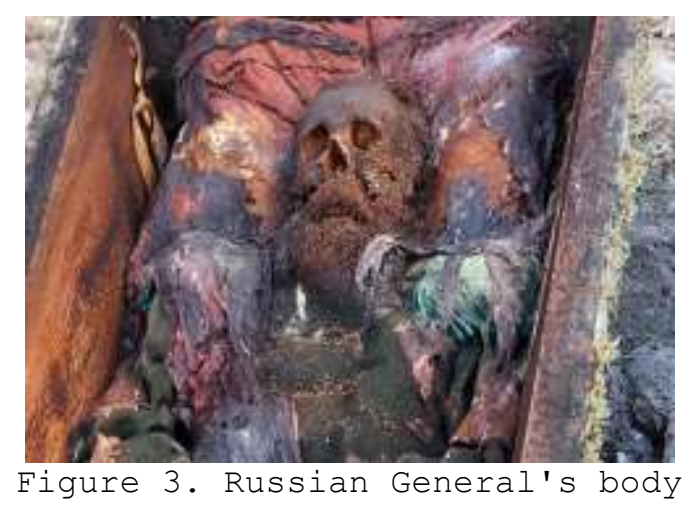

Analysis: The attention-grabbing part in the headline is the statement "mysterious events". When a human skeleton in the image of the news item which was found during a building excavation is combined with a headline like "Mysterious Events in Neighborhood", the clicking process starts. When the content of the news item is reviewed, it is found out that some belongings in the possession of neighbourhood residents in Ardahan where the skeleton was found are "mysteriously" lost. Moreover, when the news item is read in-depth, it is realised that the news item has been made by generalising the statement "I sometimes experience events that I am unable to understand" which is made by a single person in the neighborhood, Zeynepçoban, and by speculating and tabloidizingthe headline with the statement "Mysterious Events in Neighborhood".

\subsubsection{The Newspaper "Milliyet" (30.06.2017)}

Headline: Breaking News: This could be the first-ever! It was found in Şanlıurfa, its secret revealed.

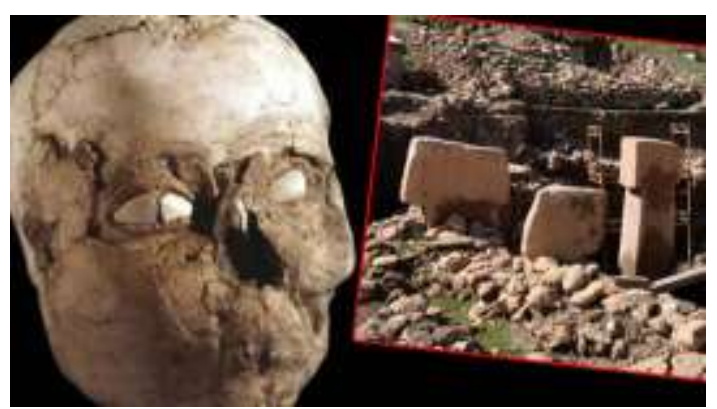

Figure 4. Archaeological provenances from Göbeklitepe 


\begin{abstract}
Analysis: In the headline of the news item, some characteristic expressions of a spreculative and tabloidised news language like "Breaking News!", "This is the first-ever", "Secret" are seen. The information given as "secret" and "first-ever" in the news item is that people cut the flesh from the bones of their dead in the prehistoric age. However, the information on defleshing the dead bodies in the pre-historic age is neither new nor a secret. In the excavations carried out in Çatalhöyük, Konya and in the pictures drawn on the walls of houses, the information on the existence of such a ritualhas already become known by the archeological science.
\end{abstract}

\title{
5.2.3. The Newspaper "Habertürk" (10.05.2017)
} revealed.

Headline: It survived in a coffin for 100 years! The secret

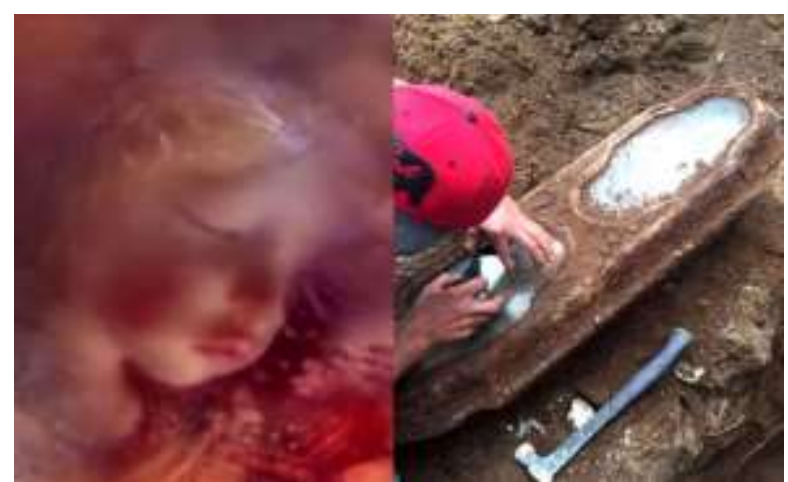

Figure 5. The photo on the left is irrelevant image about the subject. The photo on the right is body of death baby

Analysis: In the headline of the news item, there is a statement like "survive in a coffin for 100 years" and this statement is supported by an irrelevant photograph of a baby. Again, the word "secret" as one of indispensible expressions used in tabloid news takes its place in the headline. After the headline and photograph successfully get many clicks as intended, it is understood that -when the content of the news item is reviewed- the topic is irrelevant with the statements "the secret" and "survive in a coffin" as well as with the photograph used. The news item is related to finding the coffin of a baby who diedbecause of reasons like infection etc. approximately 100 years ago.

\subsection{Geology News}

\subsubsection{The Newspaper "Hürriyet" (14.06.2017)}

Headline: This view happened after

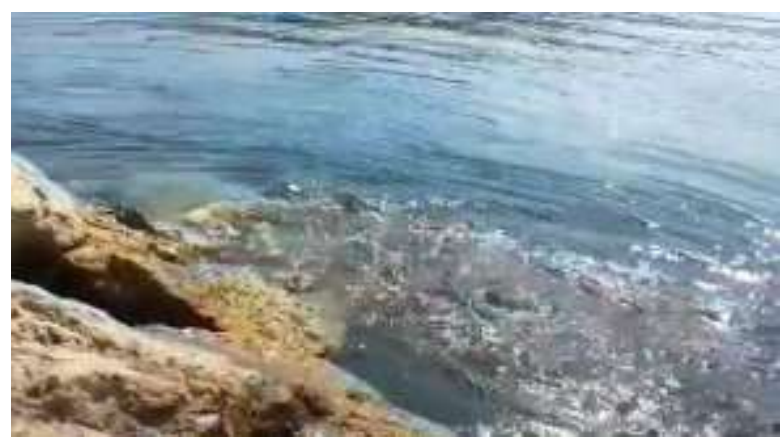

Figure 6. Some abnormalities in the sea after earthquake 
(When the photograph is clicked, the subtitle of the video appears on the screen is as follows: "Tsunami after the Aegean sea Earthquake").

Analysis: In the photograph presented with the statement "this view happened" in the headline of the news item, an obscure object is seen in the sea. As the object is not clear, it successfully arouses curiosity, generating such questions as: "Did a "weird" formation occur in the sea after the earthquake?". And the word "Tsunami" is also used in the subtitle under the photograph. When taken into account that tsunami is a term used mostly for destructive tidal waves that occur as a result of powerful earthquakes on the ground of ocean and $80 \%$ of which emerge in the Pacific Ocean; an ordinary, harmless stir in the sea are presented in the news item speculatively and by being detached from its context.

\subsubsection{The Newspaper "Milliyet" (18.08.2017)}

Headline: a 7.2-magnitude earthquake will happen

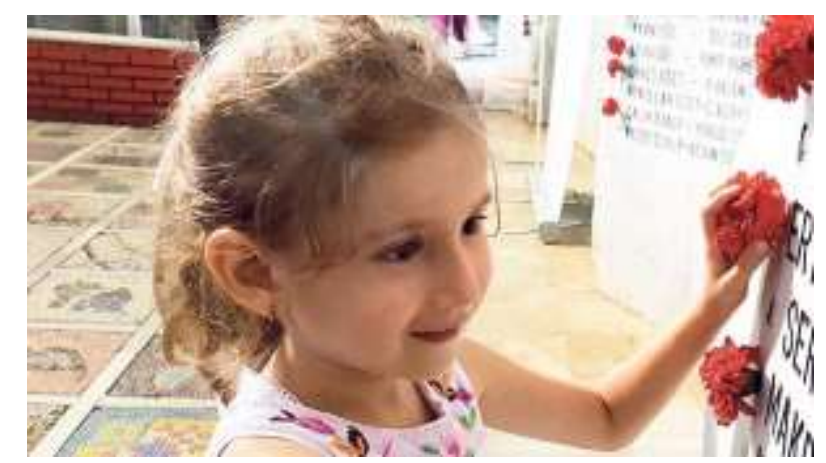

Figure 7. Child aggrieved from earthquake

Analysis: Main topic of geology news is earthquake scenarios. Two main tendencies are present in the processing way of the news articles: creating a psychology of fear and prophecies. This news item also includes elements from both of these tendencies. Statements like "next" and "magnitude" in the headline are enough to arouse an interest. However, when the content of the news item is reviewed, it is found out that Prof. H. Özener, director of Boğaziçi University The Kandilli Observatory and Earthquake Research Institute, expresses that it is not likely to give a date for a possible earthquake, however, there is a fault-line in Marmara and a 7-magnitude earthquake would not be a surprise.Despite of the fact that this discourse is very different from saying "a 7-magnitude earthquake will happen", with a certain and explicit statement, what is intended with the headline is to create a psychology of fear and present an approach of foretelling. Using a lovely girl as the image of the news item who puts flowers in front of the monument built for those who were dead in the 17 August Earthquake is also another element that detaches the news item from its original context and leads to an irrelevant sentiment.

\subsubsection{The Newspaper "Habertürk" (20.04.2017)}

Headline: Explanation regarding Earthquake from Kandilli: Next major earthquake... 


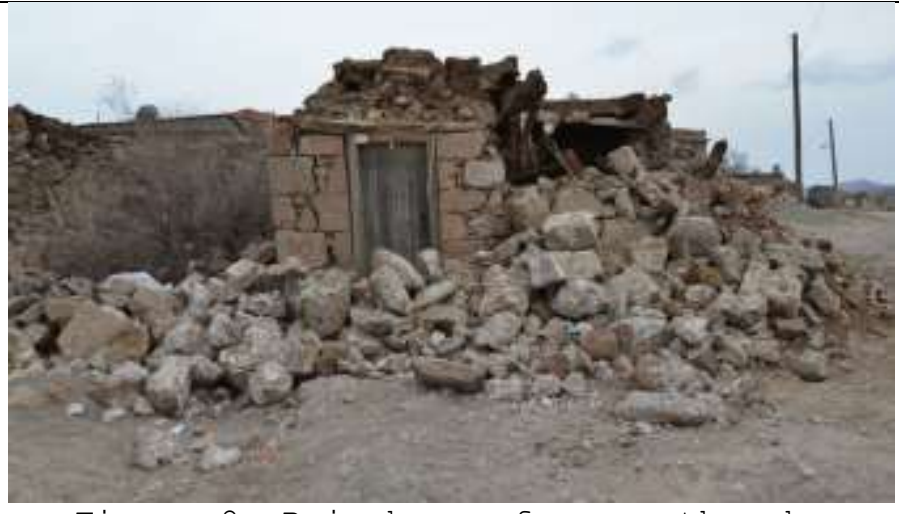

Figure 8. Ruin house from earthquake

Analysis: When the content of the news item is reviewed, it is found out that Prof. Haluközener, director of Boğaziçi University The Kandilli Observatory and Earthquake Research Institute, expresses 5/5.5-magnitude earthquakes occurred in Çanakkalein the recent days can be regarded as normal, there is no abnormality as well as answers the question "Are these small earthquakes a sign for a bigger earthquake in the Aegean Region" with the statement "It is not possible to say anything like that". However, the headline of the news item is presented with a speculative and tabloidized discourse, as if the date and the magnitude of the next earthquake were certain. The image used in the news item is a photograph describing a house that appears to be completely ruined and devastated. It is unclear on which date and where the earthquake that led to the devastation of the house in the image occurred. It is even unclear whether the image is associated with an earthquake. The only thing that is clear is that the image used supports the psychology of fear and the negative effects created by the headline "Big Earthquake".

\subsection{Astronomy News}

5.4.1. The Newspaper "Hürriyet" (02.05.2009)

Headline: Skull Enigma on Mars

Spot: These images of Mars presented on afansite of the NASA caused a sensation.
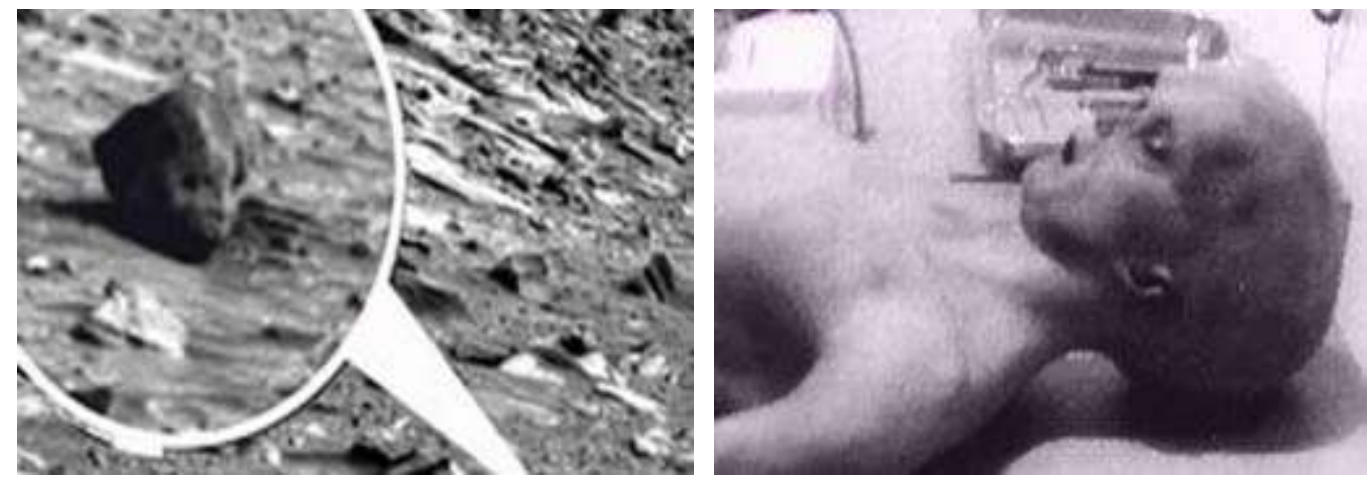

Figure 9. According to the newspaper's claimed that skull photo is fporm Mars, that "Alien" is researched by scintists

Analysis: In the headline, statements like "Mars", "Skull" and "Mystery/Enigma/Secret" are used as a characteristic sign relating tabloid language in news articles. These statements are supported by a symbolic "alien" image, which is not associated with the news item. The source of the news item is "a fansite of the Nasa", in other 
Özkan, Ö.

Humanities Sciences (NWSAHS), 4C0221, 2018; 13(1): 1-16.

words, a medium that has no scientific foundations. Written with the statements like "expressed" to be obtained from Mars (not certain who expresses), "claimed" to be an alien (who claims it?), this news article is not based upon a scientific foundation, but successfully upon a clicking-advertising foundation.

\subsubsection{The Newspaper "Milliyet" (13.12.2013)}

Headline: These Images Shook the World (Video News)

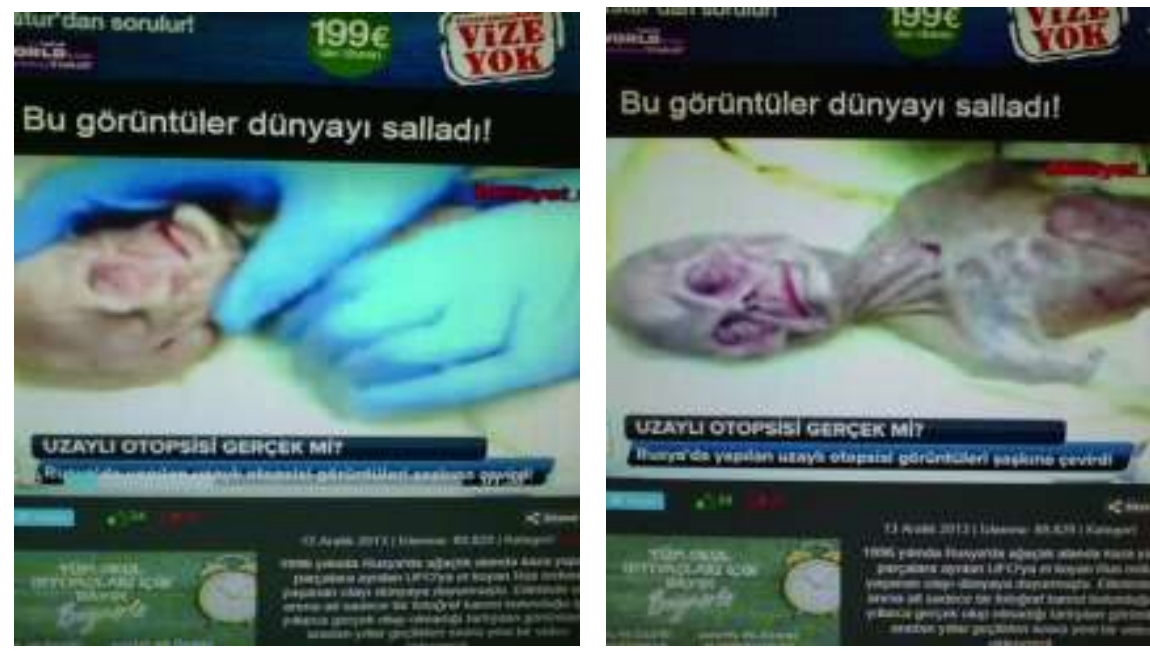

Figure 10. According to the newspaper's claim, theese images about alien autopsy

Analysis: The news item is released with the headline "Shook", another characteristic expression of the speculative language. The intriguing headline is presented together with a video that includes images of a so-called "alien autopsy", which has no scientific foundation and is not proved to be correct. When the video of the news item is watched, it is realized that these uncorroborated images are presented as if they were real and an unspecific expression like "Russian Experts" is used as source of the "images relating to the alien autopsy". It is also mentioned in the video as ifa crashed flying saucer found by a villager was real. The video news with full of "mysteries" is supported with a horror movie soundtrack.

\subsubsection{The Newspaper "Habertürk" (24.06.2015)}

Headline: This photograph from Mars!

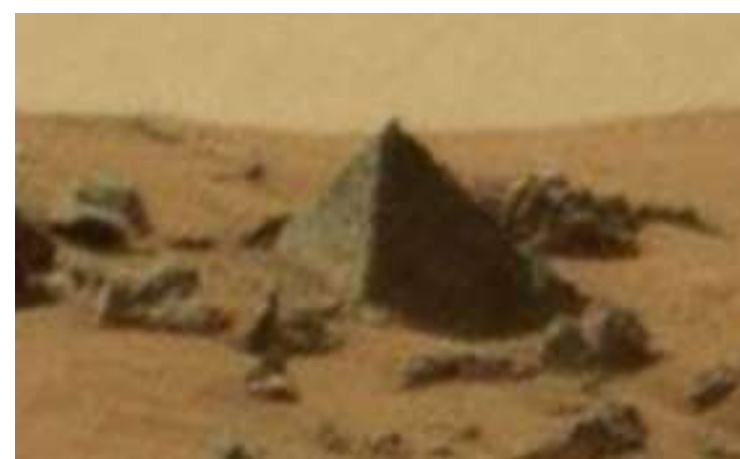

Figure 11. According to the newspaper's claim, that Pyramide photo from Mars 
Özkan, Ö.

Humanities Sciences (NWSAHS), 4C0221, 2018; 13(1): 1-16.

Analysis: The news item is presented with an image of pyramide and the headline "this photograph from Mars!" referring to the image of pyramide. When the content of the news item is reviewed, it is seen that no information about the source of the photograph is available. It is also claimed in the content of the news item that this pyramide was built deliberately. Persons like conspiracy theorists and commentators of the Paranormal Curibe in the social mediawho are not associated with scientific research and findings are presented as the source of this information. However, the headline and the news item have drawn attention to themselves and this "clicking-advertising" equation gained success.

\section{CONCLUSION AND RECOMMENDATIONS}

As stated above, the successive process beginning from the proprietary structure of the media and ending with audiences who have not developed a habit of reading affects the news structure. It is not possible to speak of news texts that inform readers accurately, in full, objectively, with a multifaceted approach and prioritise the public interest. "News headlinesplays a key role in directing readers to read the continuation of the news content. They give readers the first information about the news item and, in some way, function as a complement of news item. As they function as a complement, headlines also need to be neutral just like news items [8]." However, what is decisive in creating a news article are not these principles, but commercial concerns of media institutions. When the issue is discussed in the context of the Internet media, every way that increases the number of "clicks" are carried out, regardless of the ethical concerns. This also brings along information pollution to which news items written with a speculative language lead. What is more, it is not possible to distinguish the accurate information from the speculative one. This is something that can be distinguished only by medical personnel. According to the Özbaş and Özkan's quotation from Aktan, [9] there is a common opinion among health professionals on which effects of the media on the health matters are negative. They consider that health news articles published in the media don't reflect the truth, their aim is to create a sensation or provide adrevenue, don't give accurate information to the public. The reasons why the quality in the science news, especially in the health news is not at the desired level can be briefly expressed as follows:

- The proprietary structure of the media

- Insufficient employment of beat reporters

- Higher ad-related revenues with speculative newsitems

- The relationship between firms in the health sector and media institutions

- The presence of readers who prefer spot news that can easily be read, instead of news based on a study and containing in-depth analyses.

Along with the development and the increase of the popularity and genres in the communication technologies, news texts have become a product, rather than information. All developments that concern the general public and are worth to reporting in all disciplines of science, ranging from the astronomy to the acheology, from the geology to the health have been detached fromtheircontext. When the issue is considered in the context of areas that directly effect the human life such as health, earthquake etc., this detachment becomes more important. As expressed by Erer [10], the recent increase in the number of mass media has led to the emergence of ethical problems. This increase has, on the one hand, created a competitive environment, 
Özkan, Ö.

Humanities Sciences (NWSAHS), 4C0221, 2018; 13(1): 1-16.

on the other hand, urged people to be sceptic about the reality and accuracy of news item presented/prepared. However, it does not appear to be possible that this sceptic attitude is conducted by a society that has not adopted reading and reseaching habit according to the survey data collected by various research companies, especially by TÜIK (The Turkish Statistical Institute).

The developments occured in all disciplines of the science are one of the primary factors that determine in what way societies will reach the future and whether they will exist in future. The difference of development between the societies that initiated, carried on and developed the Industrial Revolution and those that missed it is also a sign for this. In the fourth industrial revolution in whose center artificial intelligence and nano-technology lie, it is clear that the societies having the competence to access to the scientific information and produce it will be the managers of the future world. In other words, it is required for not only scientists who consist of a limited segment of the society, but also the whole of the social structure to take part in the processes like obtaining real scientific information, adopting scientific reading and scientific thinking. In this point, it is highly important how news items are presented by the media as the primary medium via which the societies can have knowledge, whether in the field of science or in the other fields. The approach of societies towards the science is substantially shaped with the approach of the media towards the science.

The role of the media is also importantin determining to which extent societies show interest to the science. This is because the media determines what societies should think about and which topics will be on their agenda although the media does not directly say to societies what they should think.This approach expressed as the agenda-setting theory in the science of communication claims that"topics prioritized or regarded as more important by the media are also prioritized and regarded as more important in the perception of the public" [11]. In this point, when the question of at which level the viewpoint of the public towards the science and its interest in scientific developments are is asked and an extensive research on this matter are conducted, the findings obtained is far from being promising. Especially in the 1980s, various questionnaire surveys were carried outinmany countries, especially in England and the USA, in order to measure the interest shown by the public in the science. The results obtained showed that the public wasmore"illiterate" about the science than thought. As a consequence thereof, the media took a close interest in this "illiteracy" of the public and sensational news started to appear in newspapers" [12]. It can be said that, if a news language used in the media contains how much sensational content, is how detached from its scientific concept and is written with how much "clicking-advertising" motivation, its projection at the society will also appear in the same way.It is contoversial how a society whose viewpoint towards the scienceis unabletotranscend the sensational/magazinish level will take part in the future or under which circumstances it will.

The media finds a way to tabloidizethe news language for each discipline of the science. If it is read on archeology news, it is possible to encounter with 5-meter-length human skeleton found beneath the ground, weird sounds and screams coming out of the underground during excavations, findings dating back to thousands of years ago B.C. and evoking a spacecraft as well as the news items like "ancient architectural works whose construction technique is still a secret were constructed by aliens" that don't refer to a specific news source 
Özkan, Ö.

Humanities Sciences (NWSAHS), 4C0221, 2018; 13(1): 1-16.

and have no scientific foundation, however, grab attention of readers and get more clicks. When it is read on geology news, it is seen that "foretelling the future" and "propagating the psychology of fear" are the most popular approaches in the media. Information about a future earthquake which is expressed by scientists on a scientific basis and is likely to occur at a specific rate is presented by speculating like "8-magnitude earthquake is coming on that day". Moreover, when most of news items on the earthquake are reviewed, it is seen that the expression "Frightening Earthquake" is frequently used in the headlines. However, news items that inform the public and explain what is needed to do, point out the precautions to be taken within a scope, ranging from goverment policies to the individual level, in order to get over an earthquake with as little loss as possible, are relatively in the minority. It is also possible to express that the reporter making the news manipulates the scientist in line with the purpose of creating a speculative news item and directs him to speak of the worst scenario and when it can happen. In this way, a magazinish and speculative science news item which is manipulated twice, both with the speech of the scientist functioning as the news source and with the news content created by the reporter, is produced. In the astronomy news, the psychology of mystery and fear constitutes the framework on which the news bases. For example; experiments carried out at CERN, the European Organization for Nuclear Research, in search of the Higgs boson, the subatomic particle that gives the mass to substances are presented in the media with the following headlines: "Apocalyptic Experiment", "Big Bang will be Recreated", "This Experiment could bring about the end of the World". Another example is news articles related to "aliens", which are presented with fictional images as if they were real. On the one hand, the scientific information relating the search for life in the space expresses that what is searched is just an organic molecule or a single-celled organism, on the other hand, this science news articles in the media are presented with an image of alien (!) having big and evil-looking eyes as well as big head, as a rule in green color, and a discourse relating an eventual alien invasion is used in the news content.

It would be not false to say that the field that is mostly needed to put particular emphasis on among all science news is health news. Health news is news having potential to directly affect human life. When the presentation of health news in the media is reviewed, the news content appears to be tabloidized and misleading with the following methods:

- News content incompatible with its headline.Being misleading by turning a small detail from expressions of the expert functioning as the news source into a sensational expression

- Problem of reliability arising as a result of creating the news items without stating any news source or with a general expression like "Experts" as the news source

- Generating misleading news content by attributing benefits that go beyond original functionality, to any product, , with the expressions like "miracle", "cure-all".

- Relating to the illness or health problem specified in the news content, using expressions like "Fatal" and "Desperate" that urge readers to the fear and the despair as well as subjectiveemotional expressions that are needed not to exist in the news content

- Using generic expressions

- FArousing fear/anxiety against products and treatments which are subject to news item" [13]. 
Özkan, Ö.

Humanities Sciences (NWSAHS), 4C0221, 2018; 13(1): 1-16.

Some factors such as coming into existence of the Internet media recently, corporate identity in whole, unsettlement ofcorporate identity as a whole, and existence of legal gaps provide a basis for a speculative news language in news items published in this field. The applicable principle of "observance of the public interest by giving information accurately and in full" has been ignored because of the proprietary structure and commercial identity of media institutions, instead of that, the motivation for advertising has become decisive. Although the media does not determine what and how the public will think, it mainly determines what the public will think about. In this regard, the public is exposed to surreal information -instead of scientific information- of the "post-truth" chosen as the dictionary of the year 2016 by the oxford dictionary.

\section{NOTICE}

This study was presented as an oral presentation at the I. International Scientific and Vocational Studies Congress (BILMES 2017) in Nevşehir/Ürgüp between 5-8 October 2017.

\section{REFERENCES}

1. Yazıcı, T., (2013). Medya Mülkiyetine İlişkin Düzenlemeler ve Dünyadaki Örnekler Bağlamında Türkiye İçin Bir Medya Mülkiyeti Önerisi, Yayınlanmamış DoktoraTezi, T.C. Maltepe Üniversitesi Sosyal Bilimler Enstitüsü.

2. Şahin, Ö., (2012). Medya ve Demokrasi (Parlamento Muhabirleri Örneğinde), TBMM Kültür, Sanat ve Yayın Kurulu Yayınları No:145, Ankara, s.23.

3. Uzun, R., (2004). Türkiye'de Spor Basınının Etik Anlayışı, Gazi Üniversitesi İletişim Fakültesi Dergisi, Bahar-Kış, sayı:19, ss: $1-20, \mathrm{~s}: 14$.

4. Gün, E., (2013). Çok Yönlü Gazeteci Olmak, Teknoloji İle Değişen Medya, Medya Derneği ve İstanbul Şehir Üniversitesi İşbirliği ile Düzenlenen Konferans Kitabı, ss:102-103.

5. Damlapınar, Z. and Işık, U., (2017). Sağlık İçerikli Basın Haberleri ve Çocuğa Yaklaşımı: Bir İçerik Analizi, e-Gifder Gümüşhane Üniversitesi İletişim Fakültesi Elektronik Dergisi, Sayı:1, Cilt:5, ss:373-398, Mart, s:381.

6. Uzunoğlu, S., Türkiye'de Bilim Gazeteciliği Denilince İnsanların Aklına Ürün Geliyor konulu röportaj site:

http: / / diyarbakiryenigun. com/turkiyede-bilim-gazeteciligi-bilimdenilince-insanlarin-aklina-urun-geliyor/ Erişimtarihi: 23.08 .2017 .

7. Doğan, D. Haber Akademisi ve YeniGazetecilik, Korhaber sitesi Link: http://korhaber.com/yyazar.asp?haberid=849

Erişimtarihi: 28.08 .2017 .

8. Yıldız, $\dot{I}$. and Tanyıldızı, N., (2015). Türkiye'de 2012 Yılında Sağlık Haberlerinin Ulusal Yazılı Basında YerAlış Biçimleri ve Bilgilendirme Düzeyleri, Sobider Sosyal Bilimler Dergisi, Yıl:2, Sayı:2 s:122-141.

9. Özbaş, S. and Özkan, S., (2010).Kadın Sağlığını Geliştirmede Medyanın Kullanımı ve Etkisi, TAF Preventive Medicine Bulletin: $9(5), s: 541-546$.

10. (Aktardıkları kaynak: Aktan A.Ö. Toplum Sağlığı ve Geliştirme Merkezi. Medyadaki_kirliliğin_suçluları_kim._http://www.to plumsagligi.com/PageContentsPopup.aspx? $\bar{I} d=6 \overline{4} 8$ Erişimtarihi: 24.12.2009.

11. Erer, S., (2013). Kitle İletişim Araçları ve Tıp Etiği, Düzce Üniversitesi Sağlık Bilimleri Enstitüsü Dergisi, 3(3):24-28. 
Özkan, Ö.

Humanities Sciences (NWSAHS), 4C0221, 2018; 13(1): 1-16.

12. Yüksel, E., (2007). Kamuoyu Oluşturma ve Gündem Belirleme Kavramları Nerede Kesişmekte, Nerede Ayrılmaktadır?. Anadolu Üniversitesi Sosyal Bilimler Dergisi, Cilt: 7 Sayı:1, s:571-586.

13. Akoğlu, A., (2011). Bilim İletişimi, TÜBİTAK Bilim ve Teknik Dergisi, ss:24-29, Ağustos.

14. Özkan, Ö., (2016). Internet Basınında Sağlık Haberlerinin Başlık ve Spotları ile Okur Üzerindeki Yanıltıcı Etkisi, Türkbilim Dergisi, Nisan Sayı 19, ss:131-160. 